\title{
Basin Management Supported by Regional Green Innovation System and related Big Data Project Evaluation Framework in Zhejiang, East China
}

\author{
$\operatorname{Bin~} \mathrm{Li}^{*}$
}

Jiaxing University, P.O. Box 314001, Jiaxing, Zhejiang, P.R. China

\begin{abstract}
This paper explores green environment social economic innovation teams at universities in Zhejiang province, China in view of basin management. Water environment social economic system data of Qian-tang-jiang and Ou-jiang in Zhejiang province, China are estimated using " $12^{\text {th }}$ Five-year" Basin Water Pollution Prevention and Control Plan of Qian-tang-jiang and Ou-jiang in 2010, Zhejiang year-book 2014. We show that urbanization level in Zhejiang province belongs to predominantly urban level, and annual 300 million yuan was arranged for water environmental protection and water pollution control based on progressive compensation mechanism in Qian-tang-jiang. In 2013, severe Tropical Storm Fitow caused severe floods and loss reached more than 2 billion yuan. Government would solve waterborne problems fundamentally through "Governance of Water's Five Aspects", namely treating sewage water, controlling flood, draining flooded fields, supplying water and saving water. We also find that five green environment social economic innovation teams at universities in Qian-tang-jiang while one green environment social economic innovation team at universities in Ou-jiang. The case study of Qian-tang-jiang Big Data project highlight that it would be evaluated using Emergy analysis, and that more attention should be directed towards water allocation coefficient and currency exchange rate as empirical parameters.
\end{abstract}

Keywords: Baisn management, emergy, "Governance of Water's Five Aspects", green innovation team, Ou-jiang, project evaluation, Qian-tang-jiang, Zhejiang.

\section{INTRODUCTION}

Under the New Normal, urbanization level in Zhejiang province belongs to predominantly urban level. In order to solve waterborne problems caused by twin-typhoon and/or tri-typhoon, Government in Zhejiang province take the lead in promoting "Governance of Water's Five Aspects", namely treating sewage water, controlling flood, draining flooded fields, supplying water and saving water. However, "Governance of Water's Five Aspects" was carried out by city base. Therefore, concerning special ecological compensation fund, it is necessary to check river basin management supported by regional green innovation system and related Big Data project evaluation.

In this paper about Zhejiang river basin, there are seven parts, including water environment social economic system; reasons of "Governance of Water's Five Aspects"; key technologies about "Governance of Water's Five Aspects" planning; green environment social economic innovation teams at Universities; Qian-tang-jiang Big Data project evaluation conceive using emergy analysis framework.

\section{WATER ENVIRONMENT SOCIAL ECONOMIC SYSTEM IN ZHEJIANG, CHINA}

From north to south, there are eight rivers in Zhejiang province, named Tiao-xi, Great Canal, Qian-tang-jiang,
Yong-jiang, Jiao-jiang, Ou-jiang, Fei-yun-jiang and Aojiang. Qian-tang-jiang is the greatest river, occupying watershed area of 55558 square kilometers. Among them, Qiantang-jiang and Ou-jiang River " $12^{\text {th }}$ Five-year" Basin Water Pollution Prevention and Control Plan have been formulated by the Department of Environmental Protection in Zhejiang province (see both Fig. (1) and Table $\mathbf{1}$ in the next section). It was estimated that above $50 \%$ industries export virtue water of 2 billion cubic meters in 2010 [15].

In 2014, online retail sales in Zhejiang province reached 564.2 billion yuan, about $20 \%$ of China. In 2013, the province's GDP totaled 3.8 trillion yuan, accounting for $6.6 \%$ of national GDP; per capita GDP totaled 68,462 yuan, fiscal revenue 379.7 billion yuan; wastewater emission reached 4.19 billion tons, including 1.64 billion tons of industrial wastewater; Chemical Oxygen Demand (COD) emission in the waste water reached 0.76 million tons, and ammonia nitrogen emission 0.11 million tons. Zhejiang has a land area of 0.1 million square kilometers. Provincial urban per capita disposable income reached 37851 yuan, per capita net income of rural residents 16106 yuan, in the middle level among Jiangsu province, Zhejiang province and Shanghai city in the Yangtze River Delta. It could be leant by lager intra-industry trade within global and regional online and offline production networks and increasing international competitiveness $[1,11]$.

In the face of domestic economy's increasing downward pressure, complex situation of waterborne natural disasters frequently took place, Zhejiang province calmly deal with challenges, struggling to tackle tough problems and over- 
come difficulties, through in-depth implementation of " 88 strategy" and laying transformation and upgrading "combination punches".

By the end of 2011, permanent resident population reached 47.81 million, and urbanization level reached $62.3 \%$ in Zhejiang province. Urbanization level in Zhejiang province belongs to predominantly urban level, less than that of Russia, Japan and more than India [2]. And city level, county level and even town level urbanization has been progressing [3].

300 million yuan was temporarily arranged for water environmental protection and water pollution control, as special compensation funds between Anhui province and Zhejiang province supported by central government and Zhejiang province, according to transboundary water quality surveillance result, based on progressive compensation mechanism in 2011 in Xin-an-jiang, that is upstream of Qian-tang-jiang.

\section{REASONS OF “GOVERNANCE OF WATER'S FIVE ASPECTS” IN ZHEJIANG PROVINCE}

Severe Tropical Storm Fitow caused severe floods in Yuyao City, Ningbo City, Zhejiang Province in 2013 and loss reached more than 2 billion yuan. While, as many environmental protection bureau chiefs was "invited" to swim under river in Zhejiang province, from the beginning of 2013, Zhejiang undertook Pu-yang-jiang water environment comprehensive treatment campaign, promoted the province's rural clean action, established a long-term "River Chief System" for channel cleaning, and achieved initial results. Puyang-jiang is a major tributary of Qian-tang-jiang. Events of both "severe floods in Yuyao city" and "many environmental protection bureau chiefs was 'invited' to swim under river", reflected and highlighted essence of comprehensive regional development patterns, under the background of World Trade Organization (WTO) and the Basel convention, relying extensive growth consuming too much resources and environment, lack of green economy and urban vulnerability [14].

Integrity of waterborne disciplines, technologies, laws and regulations required qualitative, semi-quantitative and quantitative regional comprehensive measures. Government would solve waterborne problems fundamentally through "Governance of Water's Five Aspects", namely treating sewage water, controlling flood, draining flooded fields, supplying water and saving water. Of cause, "Governance of Water's Five Aspects" is also related with water resources congenital insufficient, population rapid increase, improving life quality, runoff, industrial development and urban greening [9]. Theoretical law basis for "River Chief System" and "Governance of Water's Five Aspects" would be revision of Environmental Protection Law of China in 2014 [8].

\section{KEY TECHNOLOGIES ABOUT "GOVERNANCE OF WATER'S FIVE ASPECTS" PLANNING IN THE WHOLE ZHEJIANG PROVINCE}

Period for Zhejiang's "Governance of Water's Five Aspects, while pollution control in advance" is across 20112015 of " $12^{\text {th }}$ Five-Year Planning" and 2016-2020 of " $13^{\text {th }}$ Five-Year Planning". During " $12^{\text {th }}$ Five-Year Planning", total quantity control is of binding and quality improvement is of instructional, while during " $13^{\text {th }}$ Five-Year Planning", both total quantity control and quality improvement is of binding [10]. "Governance of Water's Five Aspects" project's total budget is about 68 billion yuan, identifying outstanding issues to resolve in nearly three years during 20142016, requiring further enhancement of science and technology innovation ability in environmental protection field including colleges and universities, in order to realize regional sustainable development. In epoch of big data, informatization, Internet of things' active application and smart city planning, key technologies about "Governance of Water's Five Aspects" project in Zhejiang province involved in pollution control and ecological restoration for black river, stinky river and garbage river; wastewater treatment and recycling in key industries; reconstruction to meet raised effluent quality standards in urban sewage treatment plant; safety ensuring of drinking water; non-point source pollution control in agriculture and rural areas; comprehensive disposal and resource recycling for livestock and poultry breeding waste; bio-safety disposal for diseased and/or dead pig.

About half of investment for "Governance of Water's Five Aspects" project was focused in Jiaxing. Jiaxing, Zhejiang, China is near Yangtze River, Taihu Lake and Hangzhou Bay, and Grand Canal flows through Jiaxing. Distance from Jiaxing to Shanghai and Hangzhou etc. other large and medium-sized cities are less than hundred kilometers. According to geographic corresponding symmetry principle for urban spatial distribution, Jiaxing city has both inside district and outside district, five counties and/or cities, including Jiashan county, Pinghu city, Haining city, Haiyan county and Tongxiang city, namely coordination number of the city is 5 [13]. Urbanization quality is higher [12], and flow of people, material is stronger. Jiaxing government regard "Governance of Water's Five Aspects" as an important task of mass line educational practical activity, establishing public supervisor team throughout the city, setting up media "lighthouse", further, "Governance of Water's Five Aspects" was an important reference for leadership cadre selection and appointment. At the same time, as rural industrialization promoting urbanization city [16], an ecological recycling farm industry park with one thousand mu was established concerning industry regurgitation feeding agriculture in the field of agricultural circular economy, creating an "animal husbandry, cultivation and processing" industry chain, involving zero pollution industrialization project funded by National Development and Reform Commission, Ministry of Science and Technology, Ministry of Education, Ministry of Finance.

\section{GREEN ENVIRONMENT SOCIAL ECONOMIC INNOVATION TEAMS AT UNIVERSITIES IN ZHE- JIANG PROVINCE}

A national system of innovation taxonomy in EU was given, mainly including social and human capital, research capacity, technological and innovativeness performance, and absorptive capacity [13]. In China's University, rate of teacher to student is the biggest in the world; while we give a provincial level green innovation case study here. Water environment social economic system innovation is across environmental resource and circular economy. Involved in the field of environmental resources in Zhejiang province, 


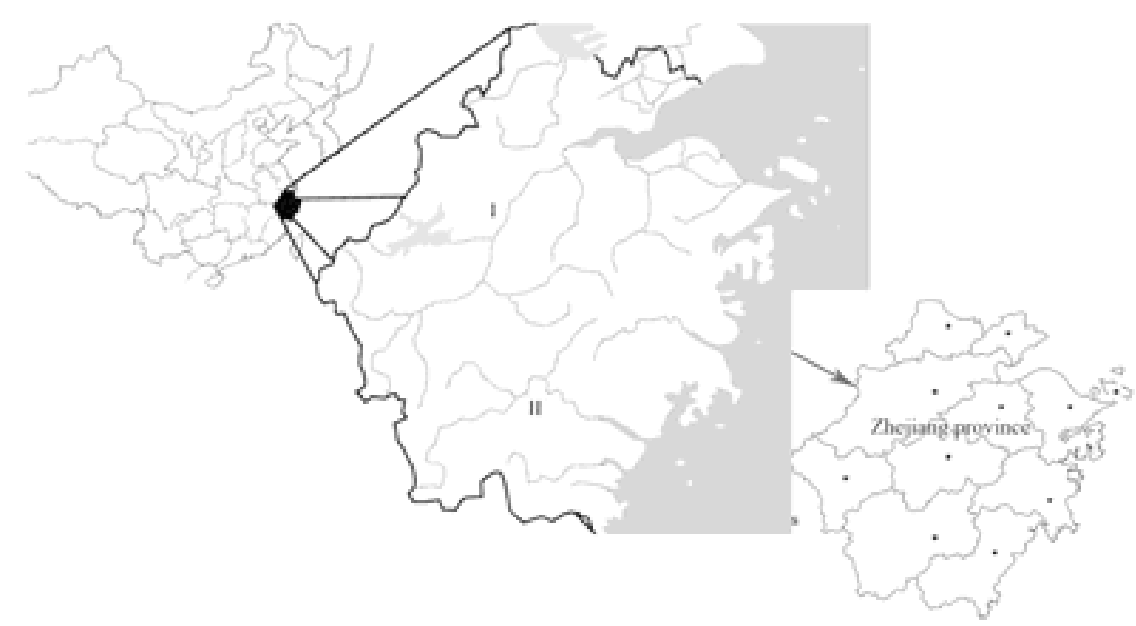

Fig. (1). Location of Qian-tang-jiang (I) and Ou-jiang River (II) in Zhejiang province, China.

Table 1. Profile of Qian-tang-jiang and Ou-jiang in Zhejiang province, China

\begin{tabular}{|c|c|c|c|c|c|c|}
\hline River basin & $\begin{array}{l}\text { River basin } \\
\text { area } \\
\left(\mathrm{km}^{2}\right)\end{array}$ & $\begin{array}{l}\text { River } \\
\text { length } \\
(\mathrm{km}) \\
\end{array}$ & $\begin{array}{l}\text { Annual } \\
\text { runoff } \\
(100 \\
\text { million } \\
\left.\mathrm{m}^{3}\right) \\
\end{array}$ & $\begin{array}{l}\text { Population } \\
\text { (ten } \\
\text { thousand) }\end{array}$ & $\begin{array}{l}\text { Cultivated } \\
\text { land area } \\
\text { (ten } \\
\text { thousand } \\
\text { mu) }\end{array}$ & $\begin{array}{l}\text { Population } \\
\text { density } \\
\left(\text { Person } / \mathrm{km}^{2}\right)\end{array}$ \\
\hline Qian-tang-jiang & 35500 & 583 & 443 & 1451 & 944 & 409 \\
\hline Ou-jiang & 18143 & 384 & 193 & 960 & 257 & 529 \\
\hline River basin & $\begin{array}{l}\text { Per capita } \\
\text { arable land } \\
\text { (mu/person) }\end{array}$ & $\begin{array}{l}\text { Per capita } \\
\text { water } \\
\text { amount } \\
\left(\mathrm{m}^{3} / \text { person) }\right.\end{array}$ & $\begin{array}{l}\text { Per acre } \\
\text { water } \\
\text { amount } \\
\left(\mathrm{m}^{3} / \mathrm{mu}\right)\end{array}$ & $\begin{array}{l}\text { Gross } \\
\text { domestic } \\
\text { product } \\
(100 \\
\text { million } \\
\text { Yuan) }\end{array}$ & $\begin{array}{l}\text { Sewage } \\
\text { discharge } \\
\text { amount } \\
\text { (ten } \\
\text { thousand } \\
\text { tons) }\end{array}$ & $\begin{array}{l}\text { Per capita } \\
\text { sewage } \\
\text { discharge } \\
\text { amount } \\
\text { (ton/person) }\end{array}$ \\
\hline Qian-tang-jiang & 0.65 & 3053 & 4693 & 8869 & 73531 & 51 \\
\hline Ou-jiang & 0.27 & 2010 & 7510 & 3570 & 11775 & 12 \\
\hline
\end{tabular}

Notes: All of data were collected just in Zhejiang province from "12 $2^{\text {th }}$ Five-year" Basin Water Pollution Prevention and Control Plan of Qian-tang-jiang and Ou-jiang in 2010, Zhejiang year-book 2014, and/ or estimated by authors.

Table 2. Green environment social economic innovation teams at Universities in Zhejiang Province, China.

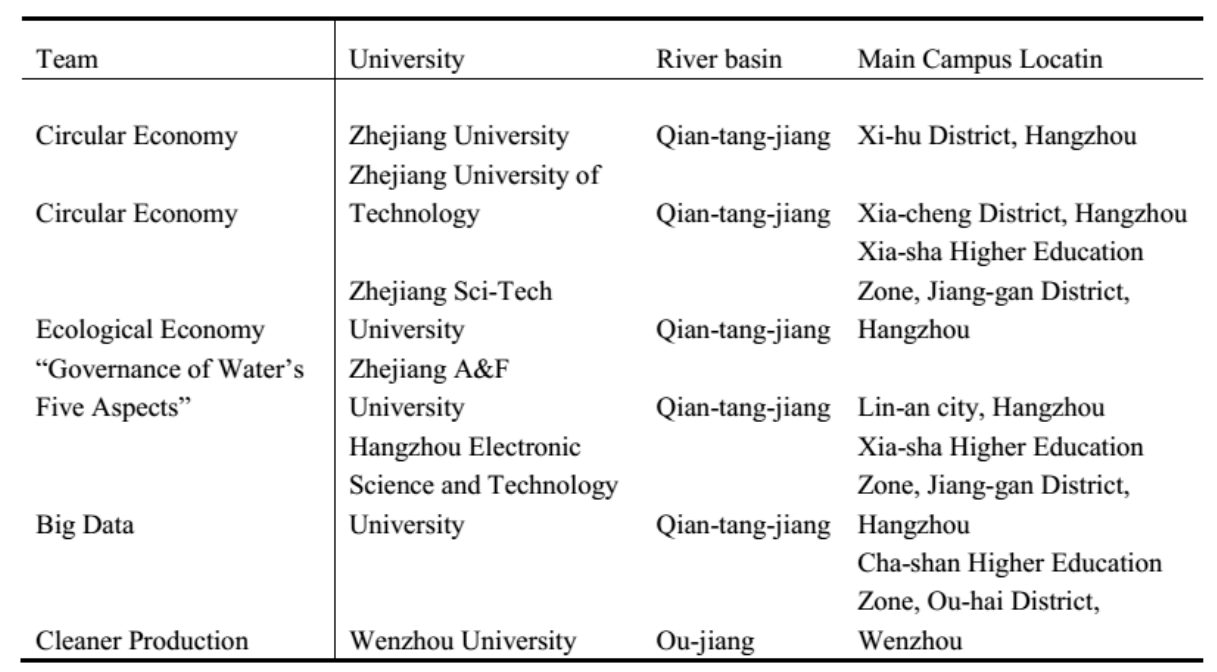


main colleges and universities are the following five universities, namely, Zhejiang University, Zhejiang University of Technology, Zhejiang Sci-Tech University, Zhejiang A\&F (Agriculture and Forestry) University, Wenzhou University, Hangzhou Electronic Science and Technology University (see Table 2). Ningbo University is expected to have great breakthrough in the field.

Zhejiang University was put forward to build "Circular Economy research center" on water governance and energyconservation and emission-reduction in Shaoxing city, including Zhejiang University's local cooperation department, College of Environmental and Resource Sciences, College of Energy Engineering, advanced control and other relevant experts; Shaoxing's Science and Technology Bureau, Environmental Protection Bureau, Development and Reform Commission, and the Municipal Water Affairs Group Company and other units. River basin and/or regional comprehensive prevention and control of water pollution, drinking water security theory and technology, new theory, new technology and new equipment for industrial wastewater treatment, promoting Shaoxing photovoltaic solar cell industry development were carried out with emphasis. Zhejiang University made regulatory conceptual scheme for Xiangtun industrial district in Dexing city. In addition, Zhejiang University held advanced study and training for circular economy development, including regional economic development in Yangtze River Delta, setting up regional characteristics of circular economy chain, modern agriculture construction and agricultural circular economy, development strategy and mode for regional circular economy, low carbon circular economy and urban sustainable development, etc.

Circular Economy research center in Zhejiang University of Technology based on key disciplines of international trade in Zhejiang province, main research directions include international trade and investment, and environment; regional ecology and circular economy; environment and resource management; cleaner production mechanism; and emission trading mechanism and so on.

Ecological economic research center in Zhejiang SciTech University based on key disciplines of regional economics and innovation team of "resources and environment, and regional economic development" in Zhejiang province, participating in such policy making as action plan for sustainable development in Zhejiang province, planning outline of Zhejiang ecological province construction and circular economy development in Zhejiang province.

Work leading group and corresponding chief expert of "Governance of Water's Five Aspects" to service Zhejiang province in Zhejiang A\&F University was set up, consisting of 6 professional working teams and specialized service teams, namely planning and design, sewage disposal, agricultural non-point source pollution control, modern agricultural development, ecological forestry construction. Action plan of "Governance of Water's Five Aspects" to service Zhejiang province was compiled, on the one hand, construction of discipline and profession and talent culture support related with "Governance of Water's Five Aspects" was further strengthened; on the other hand, existing technical achievement related with "Governance of Water's Five As- pects" was comprehensively combed in the university, transformation and practical application of related scientific research achievements was accelerated, model demonstration project was actively cooperated with local government and enterprise. Special investigations and services, focusing "Governance of Water's Five Aspects", new biogas digester, and smart agriculture construction, were carried out in Tongjia village, Tuankou town, Linan city, Huzhou city, Deqing County, and Lanxi city. "Integrated treatment technology of ecological restoration for black river and stinky river", "sewage treatment technology by using efficient microbes and modified bamboo charcoal", as well as "ecological treatment device and method for livestock and poultry breeding biogas slurry sewage", "fertilizer and its using method including biogas slurry liquid" and other related inventive patent, were initially sorted out.

Both "2011" collaborative innovation center and smart city research center were two incorporated, as an innovation model to deepen reform in Hangzhou Electronic Science and Technology University. Smart city research center consists of 11 institutes, namely big data research institute, intelligent terminal institute, smart water institute, data mining institute, etc.

Circular Economy promotion center in Wenzhou University was one of cleaner production audit institutions in Zhejiang province, having basic condition of cleaner production audit in textile chemical fiber, electroplating, leather, chemical industry, pharmaceutical, food, machinery, electronics and other industries, had engaged in cleaner production audit, Circular Economy technology and product research and promotion, cleaner production, energy audit, environmental management system and quality management system training.

\section{QIAN-TANG-JIANG BIG DATA PROJECT EVALUATION CONCEIVE USING EMERGY ANALYSIS}

Qian-tang-jiang Big Data project was undertaken by Big Data Innovation Team in Hangzhou Electronic Science and Technology University, while feed -forward neural network model, etc. was used. This project consider disaster emergency case and optimization, based on data fusion between atmospheric and water affair department.

Emergy algebra comprises two parts, namely resources and energy inputs and emission impacts. The emergy embodied into an imported product is made up of two parts, one is from geobiosphere work and the other one is from services needed for its production during previous manufacturing steps. Then emergy/dollar ratio (EDR) is calculated as follows:

\section{$\mathrm{EDR}(\operatorname{sej} / *)=\mathrm{EM}_{U} / \mathrm{GRP}=\left(\mathrm{EM}_{R N}+\mathrm{EM}_{F}-\mathrm{EM}_{\mathrm{Ex}}\right) / \mathrm{GRP}$}

where GRP is general regional product in Qian-tang-jiang river basin, EM is total emergy used; EM is renewable emergy and nonrenewable emergy; EM is feedback emergy; and EMEX is export emergy. EM includes not only solar emergy and wind emergy, but also damage due to twin typhoon. Meanwhile, EM also includes both labor and equipment, such as data building, sensor and server, etc. 
By river basin case, natural water amount, engineering water amount, and recycled water amount would be calculated. Sometimes, industries export virtue water also would be concerned. During different period of construction, operation and emergency, Qian-tang-jiang Big Data project would be evaluated based on water allocation coefficient and currency exchange rate, while not considering error of water shadow price.

\section{CONCLUSION}

In Zhejiang province, there are eight rivers, such as Qiantang-jiang, Ou-jiang, etc. Further, about one of five GDP of Taihu lake was produced in Zhejiang province. Under background of smart river basin planning introduced, giving full consideration to positioning of relevant institutions in colleges and universities related with regional circular economy, evaluation for key technology of "Governance of Water's Five Aspects", such as terahertz water, and related Big Data project in Zhejiang province were introduced. In the process of technology development, technology transfer, technical consulting, technology services to solve, teachers' entrepreneurial innovation mechanism would be explored and two-way flow of talented persons and enterprises transfer enthusiasm should be promoted. Green environment social economic innovation system would not only include three ideas of circular economy, ecological economy and low-carbon economy, but also contain Big Data water project. Obviously, green environment social economic innovation system in Qian-tang-jiang is much stronger than that in Ou-jiang.

\section{CONFLICT OF INTEREST}

The author confirms that this article content has no conflict of interest.

\section{ACKNOWLEDGEMENTS}

This work is supported by the Zhejiang Provincial Natural Science Foundation, China (No. LY12G03011), Humanities and Social Sciences Planning Fund under Ministry of Education, China (No.14YJAZH030), Jiaxing Environmental Protection Bureau (No.00512086), Circular Economy Society in Zhejiang province (00201302), South China Institute of Technology due to program of International S\&T Cooperation (Subproject, No.2011DFA60290), Chongqing University due to National Social Science Fund of China (Subproject, No.12\&ZD209), Jiaxing Science and Technology Bureau (No.2014AY11012 \& 2011AY1043), Philosophy Social Sciences Foundation in Zhejiang province (No.14NDJC005Z), Zhejiang Federation of Humanities and Social Sciences Circles (No.2013N101), Development Research Center of the State Council (No.00510323), Resource Conservation And Environmental Protection Department of
National Development and Reform Commission (No.00510322).

\section{REFERENCES}

[1] BRAKMAN S., GARRETSEN H. and VAN M.C. 2013. New economic geography: endogenizing location in an international trade model. In FISCHER Manfred M., NIJKAMP Peter (Eds.), Handbook of Regional Science. Springer Berlin Heidelberg. pp. 569-589.

[2] CARAGLiU, A., BO, C., KOURTIT, K., NIJKAMP, P. and SUZUKI, S. 2012. In search of incredible cities by means of superefficiency data envelopment analysis. Studies in Regional Science, 42(1): 129-144.

[3] DU H.Z., LI B. and DING H.J. 2009. Circular economy and regional economic development in the Zhejiang provice, southern China. International Journal of Environmental Technology and Management, 11(4): 319-329.

[4] DU H.Z., LI B., HIGANO Y. and LI Y. 2009. Circular policy on Ewaste in China- the case study of Guiyu Town, Guangdong Province. Proceedings of the 46th Annual Meeting of the Japan Section of the Regional Science Association International. Hiroshima University, Hiroshima, Japan, October 10th - 12th.

[5] DU H.Z., LI B., HU W.W. and HIGANO Y. 2008. A note on establishing a national law system to build a circular society in China. Studies in Regional Science, 38(1): 247-255.

[6] LI B., DU H.Z., BAO J.Q., HIGANO Y. and LI Y. 2011. Policy on E-waste in China - case study of Guiyu Town, Guangdong Province. Proceedings of International Conference on Computer Distributed Control and Intelligent Environmental Monitoring. 2482-2485, Changsha, Hunan, China, February 19th - 20th.

[7] LIANG H., JIANG L. and YANG K.Z. 2012. Review and prospect of theories on the evolution of urban hierarchy system. Technoeconomics \& Management Research, (10): 78-81. (in Chinese)

[8] LUO H.G. 2014. Some reflections about Government of "The Five Water". Journal of Environmental Management College of China, 24 (6): 10-12, 28. (in Chinese)

[9] SUN J.W. 2009. Regional Cooperation in Beijing-Tianjin-Hebei Metropolitan Area and Beijing International Metropolis Development Research. Intellectual Property Rights Press. (in Chinese)

[10] WANG J.N., TIAN R.S., WU S.Z. and DONG Z.F. 2010. A road map of the pollutants emission total amount control for China in the " $122^{\text {th }}$ Five-Year" Period. China Population, Resources and Environment, 20(8): 70-74. (in Chinese)

[11] Wang Y.G. 2014. A comparative study on city informatization of Beijing, Shanghai, Tianjin and Chongqing. Ecological Economy, 30(3): 56-58. (in Chinese)

[12] XIA N.K. and CHENG S. 2014. A research on index evaluation system of urban quality: case study on Zhejiang Province. Urban Planning Forum, (1): 39-45. (in Chinese)

[13] YE D.N., HE W., XU W.D. and LI Z. 2001. China's cities symmetric distribution. Scientia Sinica Terrae, 31(7): 608-616. (in Chinese)

[14] YUAN Q.D., HU T., WU Y.P., LI L.P., MAO X.Q., SHEN X.Y., YU H., PANG J. and TU Y.Y. 2011. Study on the policy system of China's green trade transformation. Environment and Sustainable Development, (3): 13-19. (in Chinese)

[15] ZHANG B.B. and SHEN M.H. 2014. Measurement of industrial virtual water trade and analysis of related influencing factors in Zhejiang Province. Journal of Zhejiang Party School of C.P.C, (5): 81-75. (in Chinese)

[16] ZHENG W.H. 2011. Research on urbanization mode of Zhejiang province based on massive economy. Journal of Anhui Agricultural Sciences, 39(36): 22492-22494. (in Chinese)

\footnotetext{
Received: September 16, 2014

Revised: December 23, 2014

Accepted: December 31, 2014

(C) Bin Li; Licensee Bentham Open.

This is an open access article licensed under the terms of the (https:/creativecommons.org/licenses/by/4.0/legalcode), which permits unrestricted, noncommercial use, distribution and reproduction in any medium, provided the work is properly cited.
} 